UDK 355.4(497.1-12)"1939/1941"(093)

355.544(497.1-12)"1939/1941"(093)

doi: $10.5937 /$ bastina30-25465

Originalni naučni rad

Dalibor Z. VELOJIĆ*

Institute for Serbian Culture - Priština / Leposavić

\title{
ASSESSMENT OF THE DEBAR DIRECTION WHEN ESTABLISHING BORDERS TOWARDS ALBANIA 1939-1941**
}

\begin{abstract}
In thepaper the assessment of the Debar direction by a commission determined to establish the border towards Albania is analyzed. The characteristics of the terrain are listed, as well as the possibilities for adequate blocking, primarily for the purpose of protection against armored units. The source of the work was the reports of the commissions, as well as the memories of the individuals involved in the evaluation and, later, in the work performance.
\end{abstract}

Key words: Kingdom of Yugoslavia Army, Macedonia, Albania, Vardar Divisional Area, establishment, Debar Operational Direction

Establishment of the Yugoslav borders was carried out more intensively in the 1930s, and similar to other European countries, taught by the experience of the First World War. The priority of the General Staff of Yugoslavia was to secure the northern and western borders, which was in accordance with the war plans and the evaluation of Italian and later German military assets (Bjelajac 1994, 206-212; Tešić 1991, 27-55; Terzić 1963, 303-309; Miletić 2017, 71-91; Velojić 2017, 145-170).

Establishment of the Albanian border had begun in the autumn of 1939. After the German invasion of the Balkan, Italy rushed to secure its positions by annexing Albania and create a good base for further operations. Germany acknowledged annexation of Albania, but Greece and Yugoslavia, although directly endangered, did not openly oppose (Pavlović 2001, 448-449). Thus, strong

* Research associate, d.velojic@yahoo.com

** This paper is written in the scope of the project Material and Spiritual Culture of Kosovo and Metohija (Record no. 178028), which was approved and financed by the Ministry of Education, Science and Technological Development, Republic of Serbia. 
Italian forces were deployed on the territory of Albania, as a potential threat to Yugoslavia, as evidenced by the outbreak of the Greco-Italian conflict in $1940 .{ }^{1}$

"The aggressiveness of Italy's foreign policy with regard to the technical development of its military force, and especially the development of moto-mechanization in its units, posed, even well before the 1941 war, the immediate danger to the former Yugoslavia and the possibility that Italy, even with the slightest diplomatic confrontation with the former Yugoslavia, undertakes a strategic attack and, rapidly penetrating by its motorized and armored units, prevents the former Yugoslavia from mobilizing and concentrating its army and preparing for resistance.

The basic idea and role of the establishment, in making this plan, is to establish a land border front with Italy in order to protect, mobilize and concentrate our army against the strategic attack and sudden penetration of Italian motorized and armored units (underlined in the original)." ${ }^{2}$

Establishment of the Albanian border, as planned, envisioned the construction of stronger barriers against combat vehicles, then securing those barriers by the construction of light fortification objects, development of secure communications for rapid possession of constructed defense objects, and the creation of shelters for crew safety during enemy bombing. According to this plan, the defense used much of the terrain characteristics to make it easier to block and create surprise for the enemy. ${ }^{3}$

Accordingly, as General Radenković stated, establishment of the Albanian border was in fact an extension of the fortification towards Italy. ${ }^{4}$ Since the penetration of armored-mechanized units is related to communications and transient land, a system of group fortification was planned, that is fortification in whichthe subdivisions are strongly organized through which the main penetration routes lead, while interspaces would be organized solely to prevent infiltration of weaker enemy parts and maintain connections between established groups. In doing so, the fortification organization of established groups could be carried out not only on the front but also in the depth, in order to reinforce persistent defense. In addition to the fortification organization in the depth in tactical terms, the plan also provided a system for determining in the depth in operational terms, which consisted of organizing several consecutive positions in the depth that formed the fortification organized zone. The lessons learned from the First World War,

1 The tension in Yugoslavia-Italy relations after strong economic crisis enters into the phase of pacification and good neighborhood relations (Stojadinović 1963, The British II 1986, Milak 1987, Krizman 1975). First of all, the economic reasons influenced the Italian government to settle relations with the neighboring country by signing the agreement in 1937, which was of mutual benefit. It was important for Yugoslavia to eliminate the Italian threat, but also to cease organizing separatist movements.

2 BA, P17, k.5, f.1, d.11/7. Statement on border establishment of General Milan Radenković.

3 BA, P16, k.8, f.1, d. 2/207. Statement on border establishment of General Dušan Simović.

4 BA, P17, k.5, f.1, d.11/7. Statement on border establishment of General Milan Radenković. 
after the use of combat vehicles, as well as the prognosis of the possible development of war technique, primarily aviation, as well as the motorization of ground forces, influenced on the post-war considerations about the ways of fortification, in which use of objects and barrier means like permanent fortification, as the only possible defensive mean, in the combat against motorized and armored units, so this type of fortification organization has found application in the most European countries. Such a system was applied by the forces of the Yugoslav army, in particular, in the mountainous, more difficult to pass zones, depth barrier was applied. When, after the entry of Italian forces into the Albanian territory, but also with the rapid penetration of the Germans into the Balkan, it became necessary to secure the border towards Albania and Bulgaria, there was no time to build stronger barriers. It is therefore planned to block directions by smaller concrete bunkers, along with the collapse of communications. ${ }^{5}$

The defense of more important border fronts, such as Italian, German and Hungarian, was entrusted to specially formed crew squads, companies, batteries and battalions, which had appropriate weapons set up on the fortification objects. At the Albanian border, since there was no stronger fortification, and therefore no crew units, security was provided by the protection units envisioned by earlier defense plans. There were no tools in the objects themselves, but the units determined for taking positions used their own weapons. ${ }^{6}$

During the General Staff of Yugoslavia planning, the entire battlefield, that isbattlefield towards Albania, was divided into three separate battlefields (zones): Zeta-Skadar, Kosovo-Podrim and Vardar-Tirana. According to the assessment of the forces and directions of action, the Vardar-Tirana battlefield was marked as the most important during the possible offensive of the Yugoslav army against Albania. By communications in this zone were the easiest to reach Tirana, which was the main target of the offensive. ${ }^{7}$ The Vardar-Tiran battlefield, from the main range of Sharr Mountains, to the Yugoslav-Greek border, was in the area of responsibility of the Vardar divisional area and matched the operational direction of the same name. That operating direction consisted of:

1. Debar-Tirana direction of action, which covered the roadsGostivar-Han Mavrovo-Žirovnica-Selita Mountain-the river valley Maća; Gostivar-Han MavrovoDebar-Ćafa Bulčizes-Tirana; Prilep-Brod-Lazaropolje-Debar (previous direction). In the case of Yugoslavian offensive. This was the most important route on the entire front.

2. Ohrid-Elbasan direction of action with the roads Tašmorunište-Krstac-ZroždTirana; Bitolj-Resan-Ohrid-Struga- to Elbasan or Tirana. The importance of this auxiliar direction was solely in close relation with the previous one.

5 Ibid.

6 Ibid.

7 Strategic-geographical assessment of our fronts and directions, Belgrade, 1922, 29. 
3. Lake direction of action, with roads Ohrid-Korča; a difficult path by the Galičica ridge; Resan-Korča. This direction of action for the Yugoslav side was irrelevant, except for securing the main forces that would act against Tirana. It was more important for the Albanian side, as it could cut most quickly through the BitolaStrugarocade bond. ${ }^{8}$

From the abovementioned, the importance of the Debar direction during the offensive operations of the Yugoslav Army is clearly emphasized. Its most important feature was the direct route to Tirana, which meant not only endangering the Albanian capital, but also splitting the Albanian and Italian troops into two parts. Defensively, this direction was not a priority for the Yugoslav military leadership, since the importance of establishing the Albanian border was transferred to the direction of Kosovo and Metohija. However, the importance of the Debar Defense Direction must not be lost from sight, since this communication, throughPolog, leads to the upper water course of Vardar and Skopje itself, whose endangerment would jeopardize relations with Greece and thus create a major strategic problem for Yugoslavia. Therefore, the security of this direction had to be implemented as part of the establishment of the entire Yugoslav-Albanian border.

The commission, led by General Milan Zelenik, formed in 1939, by order of the Minister of the Army and Navy, during studying and tactical-fortificational designing on the front towards Albania, and on the territory of the Vardar Divisional Area, presented considerations for establishing the Debar direction. First of all, according to the elaborations of the Vardar Divisional Area, the Debar route included the border front from the Čajloka River (the responsibility boundary of the Kosovo and Vardar Division Area) to the Jablanica and Kara Orman mountains. When considering the possibility of a rapid and sudden invasion of enemy armored-mechanized units, by posting the barriers, mobilization and gathering of units designated for the protection and closure of the border and the timely possession of important points and intended positions at the border would be enabled. For the commission, the significant fact was that the border line itself was planned for the defense position, parts of the Border troops reinforced by reservists, in the form of guard units and deathwatch, take positions on the border line. The part of the troops determined for the receptacles were also located near the border, while only the general reserve was located in the greater depth of the border zone. ${ }^{9}$ From the facts that the border line itself is intended as a defensive position and that most of the troops determined for the protection and closure of the border must be mobilized and gatheredcloseto the border line, as well as that in the immediate vicinity of the border the

$8 \quad$ Ibid, 30.

9 BA, P 17, k. 441, f.1, d. 11/3. Report of the Fortification Commission pg. confidential no. 16 from July 25, 1939. 
rocade communication is at the Yugoslav side, resulting difficulties in prevention against armored units. First of all, due to such a shallow arrangement of the protective troops, it is impossible to achieve the desired echelon of the barrier lines, that is, individual barrier points in the depth. Since the barrier on the one line could not be counted for sufficient security out for tactical and technical reasons, it was not possible to avoid predicting a consecutive line and a place closer to one another.

According to the information obtained, on the territory of the Vardar Divisional Area it is planned to barricade roads towards Albania solely in the immediate vicinity of the border. From these elaborations of the aforementioned divisional area, the commission did not find a support for further work, but had to carry out a subsequent reconnaissance (reconnaissance of enemy area) of the terrain and to design sites and objects not only in the first, but also in the second and third lines. ${ }^{10}$

In considering the incursion of armored-mechanized units from the Albanian side into the territory of the Vardar Divisional Area, the commission rejected that the entire border front from the Čajlska River to the western shore of Lake Ohrid implied and included in this direction. From the Albanian side to the Yugoslav border, these units would use the routes from Drač and Elbasan to Piškopeja, as well as the newly built Skadar-Piškopeja communication. All of them were channeled along the Yugoslav border into three motorways: Piškopeja-Debar, Mireški Potok-Debar and Ćafa Sane-Debar. According to reports received by the commission, it was noted that part of those communications west of Debar was unsuitable for engaging combatvehicles, so stronger activity in barrier was needed across the ridges of Dešat and Korab mountains. ${ }^{11}$

A significant object in this direction was the Debar field through which the incursion of combatvehicles is possible. The only good feature was the water course of the Rešan River, which coast on the Yugoslav side was steeper, and therefore more suitable for defense. However, on the routes near the villages of Klobučište and GornjeBlato there was a space about $2 \mathrm{~km}$ wide through which the penetration of larger units from the Albanian side could be made. The approach of the armored units can be made using the path leading from the Piškopeja, which in good weather could be observed from the Yugoslavian karaulas on the ridge of Dešat. Therefore, surprise in terms of penetration of larger units was excluded. ${ }^{12}$

The western border of the Debar field is the Black Drim River, which has a wide valley and mostly mild shores from the estuary of the Rašan River to the

10 Ibid.

11 Ibid.

$12 \mathrm{Ibid}, 11 / 4$. 
Yugoslav Kestenjar karaula. On this part, Drim spills and breaks into several sleeves, in the summer it becomes passable for people and livestock, and due to its hard soil, for combat vehicles as well. This creates new routes for the penetration of mechanized units directly towards Debar. From these data it is noticeable that passive barrier is needed in Debar itself, by trenches and mines. The focus of the barrier, however, would be made on the western edge of the town, which means shelters and artillery. ${ }^{13}$

In any case, any barrieron the Debar field required planning of works at the entrance of the straitof the Radika River in an abutment to a position that would go from Deli Senica through Pašinelivadeto the road and from there it was linked to the Stogov branches or along the Radika River to the border west of Black Drim. Although the commission here anticipated and designed the second-line barrier facility, the opinion prevailedthat, because of its importance, it should be constructed simultaneously with the first-line objects. ${ }^{14}$

Due to the importance of direction along the Radika River valley, and especially in order to provide as much as possible an important rocade road behind Korab, Dešat, Stogov and Kara Orman, the commission designed in the Radika River strait, and in front of the intersection of Gostivar and Kičevo roads, barrier object in the third line, and it was abandoned Vardar Divisional Area, planned demolition of a bridge across Mala river (by whose demolition the road for Kičevo would not blocked, and for the combat vehicles the Gostivar one as well).

In this direction it is necessary to mention the Drim and Struš sections, which, although of minor importance, were still taken into account by the commission. The Drim section scarce lacked in the communications, so it was almost unusable for combat vehicles. According to this situation, the commission did not foresee any barrier. Communication at the Struška section was critical, leading from Ćafa Sana to Struga, for which the commission designed the barrier, as well as the closure of the Struga basin through which enemy forces could threaten Debar, Kičevo and Ohrid. ${ }^{15}$

The commission's report met with disapproval that same year by another, special commission formed by order of the Minister of Defence. Its president, General Ljubiša Hadži Popović, dismissed project of General Zelenikaas illusory, leaving a barrier position in front of Debar, shifting the focus of the barrier only to Debar-Gostivar-Skopje communication. Hadži Popović, an engineering officer serving on the Determination Headquarters, believed, first of all, that easy fortification, regardless of terrain configuration and natural obstacles, would not achieve the desired goal:

13 Ibid, $11 / 6$.

14 Ibid.

15 Ibid, $11 / 8$. 
"The construction of the trenches for a standing shooter along the military edge of the position, in one or more lines, is a really weak guarantee that the position is reinforced and has gained much in its resistance (underlined in the original).

The aim of the fortification is to reduce losses and preserve the nerves of the soldiers for a decisive strike, which is not achieved through these trenches. On the contrary, soldiers are brought and held unprotected by enemy artillery fire. I know from my war experience that experienced infantry usually do not take position on those line, but dig lower, other smaller trenches, so in fact the trenches on the military edge play the role of a bait to draw artillery fire, and that is their benefit and role." 16

The most important remark, as we mentioned, was the position from the estuary of the Radika River to Black Drim and beyond, by Drim to the estuary of the Rešan River. According to him, it represented a typical reconnaissance-protective position where there was no need to carry out more extensive work. The main line would start at the exit of the Radika River from the straits, while the town of Debar itself should be fortified to the west, without the intention of receiving a more serious fight. He further suggested the construction of two communications leading from the Radika Valley, which would serve for supply and eventual retreating. The Stogovi Mountain, which is also intended to be obstructed, is mentioned in this direction as the mainstay. In the same report, General Hadži Popović wrote about a particular position for the defense of Debar (Veliki Krčin-estuary of the river Crvenica into Black Drim), divided it into sections, determined the outpost, defense and main defense lines, performing summarily and more theoretically on which land supports and which of the fortifications must be built. ${ }^{17}$

The commission's reactions to General Hadži Popovićs report were, first and foremost, that it was incomplete and that, as such, it could not be used to carry out the works. They were aware that Hadži Popović did not receive the necessary data from the headquarters of the III Army District on time, which they admitted, but still, the report had a lot offlaws. First of all, there were no data on barriers, connections, deforestation, roads, water supply, and then on anti-aircraft defense and material resources calculations. ${ }^{18} \mathrm{~A}$ compromise solution between these commissions planned stronger barrier in the Debar approaches, followed by a more detailed deployment of defense forces. ${ }^{19}$

In any case, the work on barrier was interrupted by the sudden start of the war, so that, like on the other border front to Albania, the fortification was partially implemented.

16 BA, P17, k. 518, f. 6, d. 13. Commission Report pg. confidential no. 145 from December 6, 1939.

17 Ibid.

18 BA, P 17, k. 450, f. 2, d. 15. Delegation's report of the Permanent Committee on Fortification pg. confidential no. 8 from April15, 1940.

Ibid. 


\section{SOURCES AND REFERENCES}

\section{UNPUBLISHED SOURCES}

Military Archive

Lister 16, base of purchased and donated materials

Lister 17, base of Military of Kingdom of Yugoslavia

\section{PUBLISHED SOURCES}

The British on Kingdom of Yugoslavia, organized by Živko Avramovski, Zgreb: Globus, 1986

Strategic-geographical Assessment of Our Fronts and Directions, Belgrade: the Ministry of the Army and Navy, 1922

\section{REFERENCES}

Becić 2018: I. Becić. Joint-stock Company Skopje Export Bank, Heritage, 44 (2018), 197-216.

Bjelajac 1994: M. Bjelajac, Military of Kingdom of SCS/Yugoslavia 1992-1935, Belgrade: the Insitute for Recent History of Serbia, 1994.

Velojić 2015: D. Velojić, Views of Military if Kingdom of SCS about Albania 1919-1926, Heritage, 40 (2016), 85-96.

Velojić 2017: D. Velojić, War Plans of Military of Kingdom of SCS/Yugoslavia 1922-1938, Military History Messenger, 1/2017, 145-170.

Velojić 2018: D. Velojić, War Plans of Military of Kingdom of Yugoslavia towards Albania 1938-1941, Heritage, 44 (2018), 215-229.

Krizman 1975: B. Krizman, Foreign Policy of Yugoslav State, Zagreb: Školska knjiga, 1975.

Milak 1987: Enes Milak, Italy and Yugoslavia 1931-1937, Belgrade: Institute for Contemporary History, 1987.

Miletić 2017: M. Miletić, Determining Boundaries of the Kingdom of Yugoslavia 1935-1941, Military History Messenger, 1/2017, 71-91.

Pavlović 2001: S. Pavlović, History of Balkan, Belgrade: Klio, 2001.

Ristanović 2012: P. Ristanović, Administrative Changes in the Territory of Old Serbia 1912-1941, Heritage, 32 (2012), 171-196.

Stojadinović 1963: Milan Stojadinović, Nor War Pakt, Buenos Aires, 1963.

Terzić 1963: V: Terzić, Yugoslavia in April War, Titograd, Grafički Zavod, 1963.

Tešić 1991: D. Tešić. War Plans of Military of Kingdom of Yugoslavia 1938-1941, Military

History Messenger, 1/1991, 27-55. 
Аалибор 3. ВЕАОЈИТ

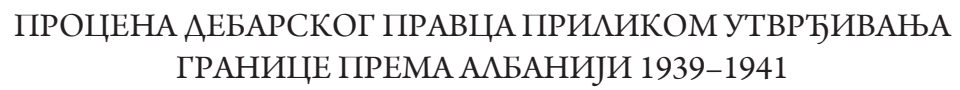

РеЗИме

Аебарски правац покривао је значајну комуникацију која је од албанске границе водима према Пологу, а затим до Скопља и горњег тока Вардара. Иако је ратним плановима југословенске војске преАвиђена бима офанзива према територији Албаније, неопходно је било извршити запречавање на овом правцу, како би се обезбедила главна комуникација која би омогућияа несметано повлачење на југ према Грчкој. Разматрање комисије за утврђивање односило се на процену терена са свим предностима и неАостацима, с обзиром на планински карактер, али и на процену расположивих снага и среАстава за запречавање. Размичити ставови које је изнео преАставник Министарства војске и морнарице Аопринели су само корекцији процене наАлежне комисије.

Кьучне речи: Војска Крањевине Југославије, Македонија, Албанија, Вардарска Аивизијске област, утврђивање, Аебарски операцијски правац.

РаА је преАат 14. фебруара 2020. године, а након мишьења рецензената, оАлуком оАговорног уредника Башйине, одобрен за штампу. 